\title{
Prevalence of previous infection with SARS-CoV-2 and persistent symptoms at a large
} university

Mark H. Ebell MD, MS (1)

David Forgacs, PhD (2)

Ye Shen, $\operatorname{PhD}(1)$

Ted M. Ross, PhD $(2,3)$

Cassie Hulme, MPH (1)

Michelle Bentivegna, MPH (1)

Hannah B. Hanley (2)

Alexandria M. Jefferson (2)

Lauren Haines (1)

1. Department of Epidemiology and Biostatistics, College of Public Health, University of Georgia.

2. Center for Vaccines and Immunology, College of Veterinary Medicine, University of Georgia.

3. Department of Infectious Diseases, College of Veterinary Medicine, University of Georgia

\section{Corresponding Author}

Mark H. Ebell MD, MS

125 BS Miller Hall, Health Sciences Campus

Department of Epidemiology and Biostatistics

College of Public Health, the University of Georgia

Athens, GA 30602

ebell@uga.edu

706-247-4953

Word count: 2733 words, 3 tables 
medRxiv preprint doi: https://doi.org/10.1101/2021.07.08.21260201; this version posted July 10, 2021. The copyright holder for this preprint (which was not certified by peer review) is the author/funder, who has granted medRxiv a license to display the preprint in perpetuity.

All rights reserved. No reuse allowed without permission.

\section{Key Points}

Question: What is the prevalence of previous infection with SARS-CoV-2 and the prevalence of persistent symptoms in university students?

Findings: In this sample of 432 students who provided saliva for $\lg A$ antibodies, we estimate that $41 \%$ to $42 \%$ had evidence of previous infection. Of 122 reporting a previous symptomatic infection, $14(11 \%)$ were still symptomatic a median of 132 days later.

Meaning: Symptomatic and asymptomatic infections with SARS-CoV-2 are common among university students, and a significant percentage had persistent symptoms over a long duration. 
medRxiv preprint doi: https://doi.org/10.1101/2021.07.08.21260201; this version posted July 10, 2021. The copyright holder for this preprint (which was not certified by peer review) is the author/funder, who has granted medRxiv a license to display the preprint in perpetuity.

All rights reserved. No reuse allowed without permission.

\section{Abstract}

Importance: Universities are unique settings with large populations, congregate housing, and frequent attendance of events in large groups. However, the prevalence of previous infection with SARS-CoV-2 in university students, including symptomatic and asymptomatic disease, is unknown.

Objective: To determine the prevalence of previous infection, risk factors for infection, and the prevalence of persistent symptoms following infection among university students.

Design: This was a cross-sectional study that surveyed students about demographics, risk factors, and symptoms, and simultaneously tested their saliva for IgA antibodies to SARS-CoV2. To estimate the prevalence of previous infection we adjusted our intentional sample of a diverse student population for year in school and age to resemble the composition of the entire student body, and adjusted for the imperfect sensitivity and specificity of the antibody test. Univariate and multivariate analysis was used to identify independent risk factors for infection.

Setting: A large public university in Athens, Georgia between January 22 and March 22, 2021.

Participants: Undergraduate and graduate students; 488 completed the survey, 432 had a valid antibody result. and 428 had both.

Exposure: Previous infection with SARS-CoV-2 based on measurement of $\lg$ A antibodies in saliva and adjustment for sample characteristics and test accuracy.

Main Outcomes and Measures: The primary outcome was the estimated prevalence of previous infection with SARS-CoV-2. Secondary outcomes were independent risk factors for infection, and the prevalence of persistent symptoms among persons reporting a previous symptomatic infection.

Results: The estimated prevalence of previous infection for 432 participants with valid antibody results was between $41 \%$ and $42 \%$. Independent risk factors for infection included male sex, having a roommate with a known symptomatic infection, and having 2 or fewer roommates. More frequent attendance of parties and bars was a univariate risk factor, but not in the 
medRxiv preprint doi: https://doi.org/10.1101/2021.07.08.21260201; this version posted July 10, 2021. The copyright holder for this preprint (which was not certified by peer review) is the author/funder, who has granted medRxiv a license to display the preprint in perpetuity. All rights reserved. No reuse allowed without permission.

multivariate analysis. Of 122 students reporting a previous symptomatic infection, 14 (11.4\%) reported persistent symptoms a median of 132 days later.

Conclusions and Relevance: Previous infection with SARS-CoV-2, both symptomatic and asymptomatic, was common at a large university. Measures that could prevent resurgence of the infection when students return to campus include mandatory vaccination policies, mass surveillance testing, and testing of sewage for antigen to SARS-CoV-2. 
medRxiv preprint doi: https://doi.org/10.1101/2021.07.08.21260201; this version posted July 10, 2021. The copyright holder for this preprint (which was not certified by peer review) is the author/funder, who has granted medRxiv a license to display the preprint in perpetuity.

All rights reserved. No reuse allowed without permission.

\section{Introduction}

It has become clear that many patients infected with SARS-CoV-2 are asymptomatic or minimally symptomatic. ${ }^{1,2}$ This is an important factor in the spread of the virus through the human population, as these persons can still spread the disease to others. ${ }^{3,4}$ Therefore, understanding the extent of asymptomatic infection is important to inform future disease control efforts.

Universities are unique settings with large populations, congregate housing, and frequent attendance of events in large groups such as sporting events, classrooms, bars, and other venues. A narrative review of cohort studies found that younger cohorts tended to have higher rates of asymptomatic infection with SARS-CoV-2. ${ }^{2}$ This was confirmed by a large cohort study of 5484 quarantined case contacts, which found that younger persons were significantly more likely to experience an asymptomatic infection than older persons. For example, only $22 \%$ of individuals 20 to 39 years of age developed a symptomatic infection compared to $65 \%$ of people over the age of 80 years. ${ }^{5}$

As of May 26, 2021 a total of 6,391 symptomatic cases have been reported at the University of Georgia in Athens, Georgia, USA (16.3\% of the 39,147 person student body). Of these, 4756 (12.1\%) occurred during $2020 .{ }^{6}$ In a previous study, we used data from reported symptomatic cases and surveillance testing of asymptomatic students to estimate that $\sim 75 \%$ of SARS-CoV-2 infections were asymptomatic. ${ }^{6}$ However, this estimate requires confirmation via populationbased testing for antibodies to SARS-CoV-2.

Typically, serum samples are used for antibody detection via enzyme-linked immunosorbent assays (ELISAs); however, saliva samples have also been used successfully for the detection of SARS-CoV-2 antibodies. ${ }^{7,8} \mathrm{IgG}$ antibody profiles from plasma and saliva are highly correlated 
medRxiv preprint doi: https://doi.org/10.1101/2021.07.08.21260201; this version posted July 10, 2021. The copyright holder for this preprint (which was not certified by peer review) is the author/funder, who has granted medRxiv a license to display the preprint in perpetuity.

All rights reserved. No reuse allowed without permission.

for other pathogens as well. ${ }^{9}$ Using $\lg A$ antibody-based SARS-CoV-2 serological tests, the majority of antibodies detected in saliva are mucosal ${ }^{10,11(\mathrm{p} 20)}$ We therefore set out to determine the prevalence of previous symptomatic and asymptomatic infection with SARS-CoV-2 in a sample of students at the University of Georgia using detection of IgA antibodies in saliva. We also sought to identify independent predictors of previous infection, as well as the proportion of students who had persistent symptoms.

\section{Methods}

This was a cross-sectional study. It was approved by the Human Subjects Committee at the University of Georgia (Version 00000889, Project 00003338). All participants gave written informed consent prior to participation. Participants were not compensated for participation; internal funding was used to purchase laboratory supplies.

\section{Population}

The University of Georgia is a large public institution in Athens, Georgia, USA with 29,765 undergraduates and 9,382 graduate and professional students enrolled in the fall semester of 2020. Students were required to be on campus during the fall semester, and faculty were encouraged to teach in person unless they obtained an Americans with Disabilities Act exemption approved by Human Resources at the University. Our goal was to identify a sample of 500 students from all levels that was representative of the student body. Because testing for SARS-CoV-2 was not required at any point during the semester, we instead obtained a list of classes that included the names of instructors, the college, the number of students allowed in the class, and the instructional level. We identified classes with at least 20 students from each of the university's 17 colleges, selecting both early undergraduate, late undergraduate, and graduate classes to develop as representative a sample as possible. We then asked instructors whether we could come to their class to identify students who would voluntarily provide saliva 
medRxiv preprint doi: https://doi.org/10.1101/2021.07.08.21260201; this version posted July 10, 2021. The copyright holder for this preprint (which was not certified by peer review) is the author/funder, who has granted medRxiv a license to display the preprint in perpetuity.

All rights reserved. No reuse allowed without permission.

samples and who would complete a one-page survey. Data collection was done by trained student volunteers.

\section{Processing of saliva samples}

Approximately $1 \mathrm{~mL}$ of saliva was collected in Bead Ruptor tubes with $1.4 \mathrm{~mm}$ ceramic beads (Omni International, Kennesaw, GA, USA). These tubes were pre-filled with $0.5 \mathrm{~mL}$ of viral transport medium containing Hanks balanced salt solution (HBSS) with $2 \%$ FBS, $100 \mu \mathrm{g} / \mathrm{mL}$ gentamicin, and $0.5 \mu \mathrm{g} / \mathrm{mL}$ Amphotericin $\mathrm{B}$, as well as $60 \mu \mathrm{l}$ of $1 \times$ cOmplete ${ }^{\mathrm{TM}}$ Protease Inhibitor Cocktail (Roche, Basel, Switzerland). Following collection, saliva samples were immediately placed in a cooler, and within one hour were refrigerated at $4^{\circ} \mathrm{C}$. They were centrifuged at 250 rpm for 30 s and stored at $-20^{\circ} \mathrm{C}$. Immediately before use, the saliva samples were heat inactivated for 45 minutes in a $56^{\circ} \mathrm{C}$ water bath to destroy any infectious SARS-CoV-2 virus in the sample. ${ }^{12}$

\section{Enzyme-linked immunosorbent assay (ELISA)}

Immulon ${ }^{\circledR} 4$ HBX plates (Thermo Fisher Scientific, Waltham, MA, USA) were coated with 100 ng/well of recombinant SARS-CoV-2 RBD protein in PBS and left overnight at $4^{\circ} \mathrm{C}$ in a humidified chamber. Plates were blocked using $2 \%$ bovine serum albumin (BSA) Fraction V (Thermo Fisher Scientific, Waltham, MA, USA) and 1\% gelatin from bovine skin (Sigma-Aldrich, St. Louis, MO, USA) in PBS/0.05\% Tween20 (Thermo Fisher Scientific, Waltham, MA, USA) at $37^{\circ} \mathrm{C}$ for $90 \mathrm{~min}$. Samples were diluted to a final saliva concentration of $1: 8$ using blocking buffer, and incubated overnight at $4^{\circ} \mathrm{C}$ in a humidified chamber. Plates were washed 5 times with PBS/0.05\% Tween20. IgA antibodies were detected using horseradish peroxidase (HRP)conjugated goat anti-human IgA detection antibody (Southern Biotech, Birmingham, AL, USA) at a 1:4000 dilution, and incubated for $90 \mathrm{~min}$ at $37^{\circ} \mathrm{C}$. Plates were then washed 5 times with 
medRxiv preprint doi: https://doi.org/10.1101/2021.07.08.21260201; this version posted July 10, 2021. The copyright holder for this preprint (which was not certified by peer review) is the author/funder, who has granted medRxiv a license to display the preprint in perpetuity.

All rights reserved. No reuse allowed without permission.

PBS/0.05\% Tween20 prior to development with $100 \mu \mathrm{L}$ of $0.1 \% 2,2$ '-azino-bis(3ethylbenzothiazoline-6-sulphonic acid) (ABTS, Bioworld, Dublin, OH, USA) solution with 0.05\% $\mathrm{H}_{2} \mathrm{O}_{2}$ for 18 minutes at $37^{\circ} \mathrm{C}$. The reaction was terminated with $50 \mu \mathrm{L}$ of $1 \%(\mathrm{w} / \mathrm{v}) \mathrm{SDS}$ (VWR International, Radnor, PA, USA). Colorimetric absorbance was measured at 414nm using a PowerWaveXS plate reader (Biotek, Winooski, VT, USA). All samples were run in duplicate and the mean of the two blank-adjusted optical density (OD) values were used in downstream analyses. IgA equivalent concentrations were calculated based on a 7-point standard curve generated by a human IgA reference protein (Athens Research and Technology, Athens, GA, USA).

\section{Determination of cutoffs for defining a positive antibody test}

The ELISA test for SARS-CoV-2 IgA antibodies was administered simultaneously with a serum test for SARS-CoV-2 IgG antibodies as a reference standard to 18 volunteers. The optimal cutoff that maximizes sensitivity and specificity at $89 \%$ was based on Youden's $\mathrm{J}$ statistic. ${ }^{13}$ The cutoff between positive and negative saliva samples was determined to be $>61.85 \mathrm{ng} / \mathrm{mL}$, and that threshold was used to define a positive or negative test for the univariate and multivariate analysis.

\section{Survey}

The survey was completed during each class period, and included questions about year of study, age, sex, race, ethnicity, type of housing, and number of room or housemates. Students were also asked whether they had experienced a previous confirmed COVID-19 infection, whether they were ever symptomatic, and whether they were still symptomatic. Finally, they were asked about adherence to face coverings and distancing, frequency of attendance of bars and parties, and whether someone they lived with had tested positive. All samples and surveys were identified by a code number only. Surveys were administered from approximately January 
medRxiv preprint doi: https://doi.org/10.1101/2021.07.08.21260201; this version posted July 10, 2021. The copyright holder for this preprint (which was not certified by peer review) is the author/funder, who has granted medRxiv a license to display the preprint in perpetuity.

All rights reserved. No reuse allowed without permission.

22 to March 22 of 2021. Data collection was halted as vaccination began among students to avoid confounding results (students were also asked to not provide a sample if they had been vaccinated).

\section{Analysis to estimate prevalence}

Sample prevalence was weighted by gender and year in school to reflect an appropriate distribution among UGA students (UGA Factbook:

https://oir.uga.edu/ resources/files/factbook/pages/UGAFactBook p20.pdf). The weighted prevalence was then further adjusted using the approach proposed by Diggle, ${ }^{14}$ as the saliva test had imperfect sensitivity. A cutoff of $>68.21 \mathrm{ng} / \mathrm{ml}$ was chosen for estimation of prevalence because it had a specificity of $100 \%$, therefore requiring only adjustment for sensitivity rather than for both sensitivity and specificity (see Appendix Table). We also chose a slightly higher cutoff of $>72.82 \mathrm{ng} / \mathrm{ml}$ (also $100 \%$ specific) as a sensitivity analysis for the estimation of prevalence.

\section{Analysis for predictors of positive antibody test}

A multivariate logistic regression model was used to assess the association between student characteristics such as demographics and behaviors and COVID-19 infection. Because of skewed distributions for some variables and small sample sizes for some categories, categories for race, year in school, and number of people sharing a household were combined for the multivariate analysis. The antibody test result was the dependent variable with age, sex, race, year in school, housing, number of people sharing a household, mask wearing off campus, numbers of parties and bars, and roommates positive as independent variables. Results are presented as adjusted odds ratios and 95\% confidence intervals. 
medRxiv preprint doi: https://doi.org/10.1101/2021.07.08.21260201; this version posted July 10, 2021. The copyright holder for this preprint (which was not certified by peer review) is the author/funder, who has granted medRxiv a license to display the preprint in perpetuity.

All rights reserved. No reuse allowed without permission.

A descriptive analysis was done to look at students reporting symptoms for a previous laboratory-confirmed positive viral test for SARS-CoV-2 infection as well as the presence of persistent symptoms at the time of survey. The length of time participants had persistent symptoms was estimated using the reported date of their positive COVID test and the midpoint of our survey data collection, February 22, 2021.

\section{Results}

A total of 497 participants were enrolled between January 20 and March 22, 2021, of whom 8 did not submit a survey, one submitted a survey but no saliva sample, and 62 who provided indeterminate or inadequate saliva samples. This left a total of 488 participants who completed the survey, 432 participants with a valid antibody result. and 428 who provided both (Table 1). The mean age of our study population was 20.6 years, $68.7 \%$ were female, and $85.3 \%$ identified as white. A previous laboratory-confirmed positive viral test for COVID-19 was reported by 140 of 488 students $(28.7 \%)$.

\section{Estimate of overall prevalence}

Among all 432 participants who provided saliva samples and had a deterministic measure of $\lg \mathrm{A}$ titers, the raw prevalence estimate was 30.0\% (95\%Cl: $26.0-34.6 \%)$ using the cutoff for prevalence estimation of $>68.21 \mathrm{ng} / \mathrm{ml}$. Most of these participants were undergraduate students $(n=392)$, and they had a raw prevalence of $30.4 \%(95 \% \mathrm{Cl}: 26.0-35.1 \%)$. After weighting by their gender and year in school, the weighted prevalence was 31.9\% (95\% $\mathrm{Cl}: 24.4-39.4 \%)$. Finally, with adjustment to account for the imperfect sensitivity of the saliva test, the estimated adjusted prevalence was $41.0 \%(95 \% \mathrm{Cl}: 31.4-50.7 \%)$. The analysis was repeated using a cutoff of $>72.82 \mathrm{ng} / \mathrm{ml}$ as a sensitivity analysis and the adjusted prevalence was estimated to be $42.2 \%(31.4-52.9 \%)$. 
medRxiv preprint doi: https://doi.org/10.1101/2021.07.08.21260201; this version posted July 10, 2021. The copyright holder for this preprint (which was not certified by peer review) is the author/funder, who has granted medRxiv a license to display the preprint in perpetuity.

All rights reserved. No reuse allowed without permission.

\section{Univariate and multivariate analysis of risk factors for infection}

In the univariate analysis, a positive antibody test was significantly more likely in male students (40.6\% vs $30.8 \%, p=0.048)$, in students reporting more than 5 attendances at bars or parties during the semester ( $41.0 \%$ vs $30.5 \%, p=0.03)$, in those with at least one roommate who had been diagnosed with COVID-19 $(40.5 \%$ vs $27.6 \%, p=0.01)$, and in those reporting 2 or fewer people sharing their residence $(39.1 \%$ vs $29.5 \%, p=0.04)$. There was no significant difference in the likelihood of a positive antibody test based on mask wearing off campus, type of housing, race, or year in school.

The multivariate analysis showed that participants who shared housing with more than two roommates during the fall 2020 semester were less likely to have received a positive COVID antibody test (OR $0.43,95 \% \mathrm{Cl} 0.24,7.74)$. Students who lived with roommates that had also received a confirmed COVID diagnosis were more likely to be positive for COVID antibodies (OR 2.01, 95\% Cl 1.23, 3.32). Social activities that include mask wearing off campus and the number of parties or bars attended did not have a significant association with a positive antibody result.

\section{$\underline{\text { Prevalence of persistent symptoms }}$}

Of the 488 participants who returned a survey, 140 participants had received a previous laboratory confirmed diagnosis of COVID (Table 3). Additional analysis of these patients showed that $122(87.1 \%)$ of the participants were experiencing symptoms at the time of diagnosis, and $14(11.4 \%)$ of participants with laboratory confirmed symptomatic COVID reported still having symptoms from their infection at the time that the survey was taken. The median duration of persistent symptoms in these 14 patients was 132 days, with a range of 12 to 253 days; 13 of 14 reported symptoms for more than 1 month, and 10 for more than 2 months. 
medRxiv preprint doi: https://doi.org/10.1101/2021.07.08.21260201; this version posted July 10, 2021. The copyright holder for this preprint (which was not certified by peer review) is the author/funder, who has granted medRxiv a license to display the preprint in perpetuity.

Comparison of previous viral testing and antibody results

In the 428 students with both survey and antibody results, 85 of $112(75.9 \%)$ reporting a previous laboratory confirmed positive viral test also were positive for salivary IgA antibodies. Of 316 students without a previous laboratory confirmed positive viral test, 60 (18.9\%) were positive for salivary $\lg A$ antibodies.

\section{Discussion}

We estimate that $41 \%$ of students had experienced a previous infection with SARS-CoV-2 at our university. Since it takes approximately 2 weeks for $\lg A$ to become detectable in saliva, ${ }^{15}$ the previous infections detected by our study represent infections from the beginning of the pandemic until approximately early February. Based on published data there were 5160 symptomatic cases reported during that period, ${ }^{16}$ whereas we estimate that the total number of cases was approximately $16,050(95 \% \mathrm{Cl} 12,292$ to 19,847$)$ in the student population of 39,147 persons. Therefore, over two-thirds of infections in university students were asymptomatic.

The extent of asymptomatic transmission has important policy and public health implications. Measures like temperature checks and apps that ask about symptoms are very unlikely to have an impact when so many infected and infectious persons at a university are asymptomatic. Measures like mandatory vaccination for students, faculty and staff, ${ }^{17}$ testing of sewage for antigen to SARS-CoV-2, ${ }^{18}$ and regular testing of the entire population ${ }^{19}$ are more likely to be effective. While many students have antibodies due to previous infection, it is not clear how durable that immunity is. Also, vaccination rates are low among young persons. For that reason, the American College Health Association recently recommended requiring COVID-19 vaccination for all students on campus in the fall of $2021 .^{20}$ 
medRxiv preprint doi: https://doi.org/10.1101/2021.07.08.21260201; this version posted July 10, 2021. The copyright holder for this preprint (which was not certified by peer review) is the author/funder, who has granted medRxiv a license to display the preprint in perpetuity.

All rights reserved. No reuse allowed without permission.

Independent predictors of infection include male sex, having a roommate who had a confirmed symptomatic infection, and having fewer than two roommates. While the number of parties and bars attended during fall semester was linearly and significantly associated with the likelihood of infection, it was not an independent predictor in the multivariate analysis. It is not clear why having fewer roommates increased the risk of previous infection. While we speculated that perhaps those with more roommates had larger "pods" and therefore felt less need to go to parties and bars, that was not the case (percentage attending more than 5 parties or bars in the semester was 34\% for those with 2 or fewer roommates and $30 \%$ for those with 2 or more, $p=$ 0.43). There may also be residual confounding with dormitory as a place of residence, which accounted for more than half of those reporting 2 or fewer roommates.

It is concerning that $11 \%$ of students who reported a previous symptomatic infection also reported persistent symptoms a median of 131 days after their initial diagnosis. Based on the total symptomatic reported infections $(n=6391)$, that suggests that approximately 700 students may be experiencing persistent symptoms. This requires further study to assess the longitudinal course of illness, the type of symptoms, and their severity in these "long-haul" patients which has not been previously reported in a population of young adults. A study in healthcare workers found that the prevalence of symptoms declined slowly over time in those with persistent symptoms, but that $15 \%$ were still experiencing symptoms 8 months later. $^{21}$

A limitation of our study is the fact that this was not a random sample of students. However, we did deliberately sample a broad range of classes, levels, and colleges to generate a diverse sample, and we also adjusted our estimate to the year and sex distribution of the university as a whole. While the saliva test is less accurate than serology, it was more practical for rapid data collection in a classroom setting, and our analysis was able to adjust for the lack of sensitivity using a validated approach. Assessment of risk factors was by self-report and there may be a degree of social desirability bias to some of the questions, such as adherence to mask-wearing 
medRxiv preprint doi: https://doi.org/10.1101/2021.07.08.21260201; this version posted July 10, 2021. The copyright holder for this preprint (which was not certified by peer review) is the author/funder, who has granted medRxiv a license to display the preprint in perpetuity.

All rights reserved. No reuse allowed without permission.

and attending parties or bars. Finally, we did not assess the type or severity of persistent symptoms.

\section{$\underline{\text { Conclusions }}$}

We estimate that over $40 \%$ of students at our university were infected with SARS-CoV-2, and that many were asymptomatic. Risk factors for infection include having an infected roommate and male sex, and approximately $11 \%$ with a symptomatic infection were experiencing persistent symptoms months later. Given low vaccination rates among young people, and the increasing prevalence of more contagious variants, mandating vaccination prior to return to campus is needed to prevent resurgence of the infection and harm to students, staff and faculty, especially as many universities have abandoned other protective measures.

\section{Acknowledgements}

The authors would like to thank Katie Mailloux, Jasmine Burris, Omar Hamwy, and Jordan Byrne for technical assistance. The recombinant proteins were produced by Jeffrey Ecker, Spencer Pierce, Ethan Cooper, and the team in the Center for Vaccines and Immunology protein production core. The authors would also like to thank Emma Calhoun Ellis, Caroline Johnston, Mary Anne E. Roach, Caroline Lindsey, Ansley Connelly, and Yazan Bouchi for their assistance with data collection 
medRxiv preprint doi: https://doi.org/10.1101/2021.07.08.21260201; this version posted July 10, 2021. The copyright holder for this preprint (which was not certified by peer review) is the author/funder, who has granted medRxiv a license to display the preprint in perpetuity. All rights reserved. No reuse allowed without permission.

Table 1. Characteristics of study participants with both valid antibody result and completed survey $(\mathrm{n}=428)$

\section{Antibody Result \\ (> $61.85 \mathrm{ng} / \mathrm{ml}$ )}

\begin{tabular}{ccc}
\hline Total & Positive & Negative \\
$(\mathrm{N}=428)$ & $(\mathrm{N}=145)$ & $(\mathrm{N}=283)$
\end{tabular}

Age

Mean (SD)

$20.6(2.28)$

$20.4(2.20)$

$20.7(2.32)$

Sex

Male

$133(31.1 \%) \quad 54(37.2 \%) \quad 79(27.9 \%)$

Female

$294(68.7 \%)$

$91(62.8 \%)$

$203(71.7 \%)$

Other

$1(0.2 \%)$

$0(0 \%)$

$1(0.4 \%)$

Race

Alaska Native/Native American

$1(0.2 \%)$

$0(0 \%)$

$1(0.4 \%)$

Asian/Pacific Islander

$21(4.9 \%)$

$10(6.9 \%)$

$11(3.9 \%)$

Black/African American

$21(4.9 \%)$

$4(2.8 \%)$

$17(6.0 \%)$

White

$365(85.3 \%)$

$125(86.2 \%)$

$240(84.8 \%)$

Multi-racial

$18(4.2 \%)$

$5(3.4 \%)$

$13(4.6 \%)$

Not reported

$2(0.5 \%)$

$1(0.7 \%$

$1(0.4 \%)$

\section{Year in School}

Undergraduate year $1 / 2$

Undergraduate year $3 / 4 / 5$

$177(41.4 \%) \quad 64(44.1 \%) \quad 113(39.9 \%)$

Graduate or professional

$216(50.5 \%) \quad 70(48.3 \%) \quad 146(51.6 \%)$

$35(8.2 \%) \quad 11(7.6 \%) \quad 24(8.5 \%)$

\section{Housing}

UGA Dormitory

$117(27.3 \%) \quad 43(29.7 \%) \quad 74(26.1 \%)$

Fraternity/Sorority House

$42(9.8 \%)$

$13(9.0 \%)$

$29(10.2 \%)$

Apartment/Condo

$185(43.2 \%) \quad 59(40.7 \%) \quad 126(44.5 \%)$

Living at home with

$21(4.9 \%)$

$8(5.5 \%)$

$13(4.6 \%)$

parents/guardians

Rental or other home

$63(14.7 \%) \quad 22(15.2 \%) \quad 41(14.5 \%)$ 
medRxiv preprint doi: https://doi.org/10.1101/2021.07.08.21260201; this version posted July 10, 2021. The copyright holder for this preprint (which was not certified by peer review) is the author/funder, who has granted medRxiv a license to display the preprint in perpetuity.

\section{Number sharing household}

0-2 roommates

$>2$ roommates

Missing

\section{Mask wearing off campus}

Almost always

Sometimes

Rarely or never

Number of parties/bars attended during fall semester

0-1 time

2-5 times

6-10 times

11 or more times

\section{At least one roommate positive}

Yes

No

Missing

$\begin{array}{ccc}197(46.0 \%) & 77(53.1 \%) & 120(42.4 \%) \\ 217(50.7 \%) & 64(44.1 \%) & 153(54.1 \%) \\ 14(3.3 \%) & 4(2.8 \%) & 10(3.5 \%)\end{array}$

$230(53.7 \%) \quad 78(53.8 \%) \quad 152(53.7 \%)$

$148(34.6 \%) \quad 53(36.6 \%) \quad 95(33.6 \%)$

$49(11.4 \%) \quad 14(9.7 \%) \quad 35(12.4 \%)$

$180(42.1 \%) \quad 53(36.6 \%) \quad 127(44.9 \%)$

$109(25.5 \%) \quad 35(24.1 \%) \quad 74(26.1 \%)$

$50(11.7 \%) \quad 18(12.4 \%) \quad 32(11.3 \%)$

$89(20.8 \%) \quad 39(26.9 \%) \quad 50(17.7 \%)$

$195(45.6 \%) \quad 79(54.5 \%) \quad 116(41.0 \%)$

$228(53.3 \%) \quad 63(43.4 \%) \quad 165(58.3 \%)$

$5(1.2 \%) \quad 3(2.1 \%) \quad 2(0.7 \%)$ 
medRxiv preprint doi: https://doi.org/10.1101/2021.07.08.21260201; this version posted July 10, 2021. The copyright holder for this preprint (which was not certified by peer review) is the author/funder, who has granted medRxiv a license to display the preprint in perpetuity.

All rights reserved. No reuse allowed without permission.

Table 2. Results of multivariate logistic regression with presence of antibodies (> $61.85 \mathrm{ng} / \mathrm{ml}$ ) as the dependent variable.

\begin{tabular}{|c|c|c|}
\hline Risk factor & Adjusted odds ratio $(95 \% \mathrm{Cl})$ & $\mathbf{p}$ \\
\hline Age (years) & $0.97(0.84-1.13)$ & 0.698 \\
\hline Male sex & $1.66(1.03-2.67)$ & 0.036 * \\
\hline Non-white race & $1.05(0.49-2.26)$ & 0.896 \\
\hline \multicolumn{3}{|l|}{ Year in school } \\
\hline Undergraduate year $1 / 2$ & REF & \\
\hline Undergraduate year $3 / 4 / 5$ & $0.92(0.46-1.82)$ & 0.803 \\
\hline Graduate & $0.62(0.18-2.17)$ & 0.453 \\
\hline \multicolumn{3}{|l|}{ Housing } \\
\hline Dormitory & REF & \\
\hline Greek & $1.08(0.38-3.04)$ & 0.884 \\
\hline Apartment & $1.57(0.70-3.50)$ & 0.273 \\
\hline At home & $2.68(0.87-8.22)$ & 0.085 \\
\hline Rental home & $2.24(0.82-6.11)$ & 0.117 \\
\hline \multicolumn{3}{|l|}{ Masks wearing off campus } \\
\hline Almost always & REF & \\
\hline Sometimes & $1.01(0.61-1.67)$ & 0.968 \\
\hline Rarely or never & $0.56(0.26--1.20)$ & 0.134 \\
\hline \multicolumn{3}{|l|}{$\begin{array}{l}\text { Number of parties and bars } \\
\text { attended during fall semester }\end{array}$} \\
\hline 0 to 1 & REF & \\
\hline 2 to 5 & $1.11(0.63-1.99)$ & 0.708 \\
\hline 6 to 10 & $1.19(0.55-2.55)$ & 0.658 \\
\hline $11+$ & $1.65(0.86-3.15)$ & 0.130 \\
\hline At least one roommate positive & $1.92(1.18-3.12)$ & 0.009 * \\
\hline Number sharing housing $>2$ & $0.41(0.23-0.72)$ & 0.002 * \\
\hline
\end{tabular}

${ }^{*} p<0.05$ 
medRxiv preprint doi: https://doi.org/10.1101/2021.07.08.21260201; this version posted July 10, 2021. The copyright holder for this preprint (which was not certified by peer review) is the author/funder, who has granted medRxiv a license to display the preprint in perpetuity. All rights reserved. No reuse allowed without permission.

Table 3. Characteristics of participants with previous confirmed COVID-19 infection

\section{Confirmed Covid}

$(\mathrm{N}=140)$

\section{Symptoms}

Yes

$122(87.1 \%)$

No

$18(12.9 \%)$

Persistent Symptoms

Yes

$14(10.0 \%)$

No

$126(90.0 \%)$

Number of Days with Persistent Symptoms $(n=14)$

Mean (SD)

$132(22.5)$

Median [Min, Max]

$131[12,253]$ 
medRxiv preprint doi: https://doi.org/10.1101/2021.07.08.21260201; this version posted July 10, 2021. The copyright holder for this preprint (which was not certified by peer review) is the author/funder, who has granted medRxiv a license to display the preprint in perpetuity.

All rights reserved. No reuse allowed without permission.

\section{References}

1. Buitrago-Garcia D, Egli-Gany D, Counotte MJ, et al. Occurrence and transmission potential of asymptomatic and presymptomatic SARS-CoV-2 infections: A living systematic review and meta-analysis. PLoS Med. 2020;17(9):e1003346. doi:10.1371/journal.pmed.1003346

2. Oran DP, Topol EJ. Prevalence of Asymptomatic SARS-CoV-2 Infection $\square:$ A Narrative Review. Ann Intern Med. Published online 2020. doi:10.7326/M20-3012

3. Lee S, Kim T, Lee E, et al. Clinical Course and Molecular Viral Shedding Among Asymptomatic and Symptomatic Patients With SARS-CoV-2 Infection in a Community Treatment Center in the Republic of Korea. JAMA Intern Med. Published online August 2020. doi:10.1001/jamainternmed.2020.3862

4. McEvoy D, McAloon C, Collins A, et al. Relative infectiousness of asymptomatic SARSCoV-2 infected persons compared with symptomatic individuals: a rapid scoping review. BMJ Open. 2021;11(5):e042354. doi:10.1136/bmjopen-2020-042354

5. Poletti P, Tirani M, Cereda D, et al. Association of Age With Likelihood of Developing Symptoms and Critical Disease Among Close Contacts Exposed to Patients With Confirmed SARS-CoV-2 Infection in Italy. JAMA Netw Open. 2021;4(3):e211085. doi:10.1001/jamanetworkopen.2021.1085

6. Ebell MH, Chupp C, Bentivegna M. A high proportion of SARS-CoV-2-infected university students are asymptomatic. J Fam Pract. 2020;69(9):428-429.

7. Chohan BH, Lavreys L, Mandaliya KN, et al. Validation of a modified commercial enzymelinked immunoassay for detection of human immunodeficiency virus type 1 immunoglobulin G antibodies in saliva. Clin Diagn Lab Immunol. 2001;8(2):346-348. doi:10.1128/CDLI.8.2.346-348.2001

8. MacMullan MA, Ibrayeva A, Trettner $\mathrm{K}$, et al. ELISA detection of SARS-CoV-2 antibodies in saliva. Sci Rep. 2020;10(1):20818. doi:10.1038/s41598-020-77555-4

9. Hettegger $\mathrm{P}$, Huber $\mathrm{J}$, Paßecker $\mathrm{K}$, et al. High similarity of IgG antibody profiles in blood and saliva opens opportunities for saliva based serology. PloS One. 2019;14(6):e0218456. doi:10.1371/journal.pone.0218456

10. Varadhachary A, Chatterjee D, Garza J, et al. Salivary anti-SARS-CoV-2 IgA as an accessible biomarker of mucosal immunity against COVID-19. MedRxiv Prepr Serv Health Sci. Published online August 11, 2020. doi:10.1101/2020.08.07.20170258

11. Mak T, Saunders M. Chapter 20 - Mucosal and Cutaneous Immunity. In: The Immune Response - Basic and Clinical Principles. Academic Press; 2006:583-609. doi:https://doi.org/10.1016/B978-012088451-3.50022-3

12. Jureka AS, Silvas JA, Basler CF. Propagation, Inactivation, and Safety Testing of SARSCoV-2. Viruses. 2020;12(6). doi:10.3390/v12060622

13. Youden WJ. Index for rating diagnostic tests. Cancer. 1950;3(1):32-35. doi:10.1002/10970142(1950)3:1<32::aid-cncr2820030106>3.0.co;2-3 
medRxiv preprint doi: https://doi.org/10.1101/2021.07.08.21260201; this version posted July 10, 2021. The copyright holder for this preprint (which was not certified by peer review) is the author/funder, who has granted medRxiv a license to display the preprint in perpetuity.

All rights reserved. No reuse allowed without permission.

14. Diggle PJ. Estimating Prevalence Using an Imperfect Test. Epidemiol Res Int. $2011 ; 2011: e 608719$. doi:10.1155/2011/608719

15. CDC. Interim Guidelines for COVID-19 Antibody Testing. Centers for Disease Control and Prevention. Published February 11, 2020. Accessed June 17, 2021.

https://www.cdc.gov/coronavirus/2019-ncov/lab/resources/antibody-tests-guidelines.html

16. Times TNY. Tracking Coronavirus Cases at U.S. Colleges and Universities. The New York Times. https://www.nytimes.com/interactive/2021/us/college-covid-tracker.html. Published February 26, 2021. Accessed June 17, 2021.

17. Gostin LO, Shaw J, Salmon DA. Mandatory SARS-CoV-2 Vaccinations in K-12 Schools, Colleges/Universities, and Businesses. JAMA. Published online June 7, 2021.

doi:10.1001/jama.2021.9342

18. Gibas C, Lambirth K, Mittal N, et al. Implementing building-level SARS-CoV-2 wastewater surveillance on a university campus. Sci Total Environ. 2021;782:146749.

doi:10.1016/j.scitotenv.2021.146749

19. Rennert L, McMahan C, Kalbaugh CA, et al. Surveillance-based informative testing for detection and containment of SARS-CoV-2 outbreaks on a public university campus: an observational and modelling study. Lancet Child Adolesc Health. 2021;5(6):428-436. doi:10.1016/S2352-4642(21)00060-2

20. ACHA Recommends COVID-19 Vaccination Requirements for Fall 2021. Accessed June 17, 2021. https://www.acha.org/ACHA/About/ACHA_News/ACHA_Recommends_COVID19_Vaccination_Requirements_for_Fall_2021.aspx

21. Havervall S, Rosell A, Phillipson M, et al. Symptoms and Functional Impairment Assessed 8 Months After Mild COVID-19 Among Health Care Workers. JAMA. 2021;325(19):2015-2016. doi:10.1001/jama.2021.5612 